\title{
Moderate Islamic Da'wah in the New Normal Era (KH. Afifuddin Muhajir And KH. Abdul Moqsith Ghazali Online Reading Study)
}

\author{
Jamal Ma'mur Asmani* \& Ah. Dalhar Muarif \\ Institut Pesantren Mathali'ul Falah Pati \\ *Corresponding Author: jamal@ipmafa.ac.id
}

\begin{abstract}
Islamic da'wah through online media is able to provide another form of delivering da'wah in the new normal era. The development of public opinion must be balanced with news that is peaceful, therefore it is necessary to preach about moderate Islam. Among the figures who preach via social media are KH. Afifuddin Muhajir and KH. Abdul Moqsith Ghazali. Moderate Islam has a character based on divinity, based on the instructions of the prophet, compatible with human nature, free from conflict, steady and consistent, universal and comprehensive, wise, balanced and free from excessive actions. The method used in this study is a qualitative method. This study uses a phenomenological approach. Analysis using discourse content analysis. This research takes data from You Tube content. Afifuddin Muhajir and KH. Abdul Moqsith Ghazali. Moderate Islamic da'wah carried by KH. Afifuddin Muhajir and KH. Abdul Moqsith Ghazali provides a high portion of reasoning and is oriented towards human respect. Both of them are experts in ushul fiqh and study Sufism, so that these two disciplines greatly influence their thinking so that they have a rationalist-humanist pattern. rationalist-humanist is da'wah in the way of thinking al-adalah, at-tawazun, attawasuth and at-tasamuh which makes human beings an object that should be respected and valued as a creature of God's creation.
\end{abstract}

Keywords: Moderate Islamic Da'wah, Online Reading, Rationalists Humanist

\section{Introduction}

Facing a radical ideology that likes to mislead others and believes that the blood of those who disagree with it is lawful, there is no other way but to develop a moderate Islamic paradigm characterized by moderation, tolerance, and progression that respects local treasures. This paradigm must be revitalized so that it becomes the mainstream paradigm of Indonesian Islam. It is this paradigm that is able to combine the dimensions of Islam and nationality so that nationalism and national patriotism continue to be firmly embedded in the hearts of the country's children. 
Further, based on a survey conducted by the Wahid Institute in 2020 explained that the trend of intolerance and radicalism in Indonesia tends to increase from time to time. This tendency is influenced by several factors, especially political contestation, lectures or speeches containing hate speech and uploads containing hate speech on social media. Based on the results of a study conducted by the Wahid Institute, there are around $0.4 \%$ or approx 600,000 Indonesian citizens (WNI) who have taken radical actions. The data is calculated based on the adult population, which is around 150 million people and there are also groups of people who are prone to being affected by radical movements, namely those who can do it carry out radical movements if invited or there is an opportunity with a total of around 11.4 million people or 7.1\%. Meanwhile, the attitude of intolerance in Indonesia, according to Yenny, also tends to increase from the previous around $46 \%$ and currently to $54 \%$ (Rahmanto, 2021).

This moderate Islamic paradigm is absolutely necessary to develop considering that radicalism, fundamentalism, and religion-based terrorism are still a serious threat to the nation. The characteristics of this radical group are absolute textual. Textual is understanding the Qur'an and hadith literally without looking at the socio-cultural and political setting when the text was born. Absolute is to believe in the truth that he believes as a single truth, so he does not tolerate differences of opinion.

There are at least 3 main reasons why pesantren can carry out a central function in relation to strengthening moderate Islam (Hannan, 2018):

a. Moderate Islam is identical with the wasahtiyyah principle. The majority of Islamic boarding schools are affiliated with nu which teaches al-is, at taubah, at tawazun and at tasamuh.

b. Aspects of religious rituals with local nuances. Islamic boarding schools have the advantage of adapting to the environment.

c. The existence of a kiai figure who is a symbol of religion and power.

One of the figures in the spread of moderate Islam in Indonesia are the kiai and santri. The moderation of the kiai and santri is strengthened by the spirit of nationalism embedded in the soul. They learn and teach the nation's cadres. In the midst of society, they struggle to spread knowledge and empower the community from the moral, educational, economic, cultural and national political aspects. Since 
pre-independence, they devote their soul and body to expel the invaders who exploit Indonesia's human and natural resources in an inhumane way and away from the values of justice.

The moderation character of Islam according to Quraish Shihab describes the moderate nature possessed by Muslims, namely not leaning towards exaggeration (ifrath) or even underestimating (tafrith) in various issues that are related to religion and the world. not including those who are extreme in religion and not including those who annul religious provisions (Zamimah, 2018).

The moderation of the kiai's thinking is based on several things, namely: First, in carrying out the teachings of Islam, the kiai adheres to a madzhab system. Kiai did not set the law directly with the Qur'an and the hadith of the Prophet, but with the ideas of scholars known as absolute mujtahids, namely Imam Shafii, Imam Hanafi, Imam Maliki, and Imam Hambali. This bermadzhab is done textually (qauli) by quoting the opinions of scholars in books and methodologically (manhaji) by applying the science of ushul fiqh and qawaid fiqh to respond to actual social problems. This qauli and manhaji practice gave birth to various forums for the study of kiai at Nahdlatul Ulama, starting with bahtsul masail diniyah waqi'iyyah (study of practical religious issues), bahtsul masail diniyah maudhu'iyyah (study of contemporary themes), and bahtsul masail diniyah. qanuniyyah (study of statutory issues). This choice of madhhab encourages the kiai to conduct extensive intellectual exploration by examining the products of thought by scholars, both classical and contemporary, which are affiliated to the madhhab. Of the four madhhabs above, the Imam Shafii madhhab is very dominantly followed. The Imam Shafii school is known as a school that is able to combine ahl ra'yi (rationalists) and ahlul hadith (textuals). Imam Syafii has two products of thought, namely qaul qadim (old opinion when in Baghdad) and qaul Jadid (new opinion when in Egypt). Imam Syafii's dynamic thinking distances the static, rigid, and stagnant character. Therefore, the kiai's thinking is always dynamic and relevant to the challenges of the times.

Second, the orientation of the kiai's thinking always leads to social benefits. In the NU adage it is stated "al-ahkamu raji'atun ila mashalihil ummah fil ma'asyi wal ma'adi" the law returns to the benefit of the people in the world and the hereafter. Benefit is to bring benefit and prevent harm. Benefit is strengthened Right by maintaining the five basic rights (al-ushul al-khamsah), namely guarding religion, 
guarding the soul, guarding property, guarding reason, and guarding offspring. It was this benefit orientation that gave birth to phenomenal decisions from the womb of NU that strengthened aspects of nationality and diversity. According to Zastro Ngatawi (2009), NU prefers Darus Salam (State of Peace) for Indonesia, rather than Darul Islam (Islamic State) or Darul Harbi (State of War). When there was a crisis of legitimacy for national leadership, NU gave Bung Karno the title Waliyyul Amri AlDharuri Bisy Syaukah (emergency leader supported by the power of the community) so that political instability would not occur which endangered the unity and integrity of the nation. KH. M. Hasyim Asy'ari as Rais Akbar NU issued a jihad resolution on October 22, 1945 which obliges Muslims to take up arms to defend the independence that has been achieved. All of these are oriented towards substantial benefits, namely maintaining independence and maintaining national unity.

Third, the kiai's paradigm of thought is tawassuth (moderate), tasamuh (tolerant), tawazun (balanced), and i'tidal (perpendicular). The moderation of the kiai's thinking is indicated by the accommodation of the naqli (text) and aqli (ratio) propositions, between ilahiyah (divinity) and insaniyah (humanity), and between liberals and radicals. NU's tolerance is shown by good relations with fellow Muslims and non-Muslims. KH. Ahmad Shiddiq, former Rais Am NU formulated a trilogy of ukhuwwah, namely ukhuwwah Islamiyyah (brotherhood between fellow Muslims), ukhuwwah wathaniyyah (brotherhood between fellow children of the nation), and ukhuwwah basyariyah (brotherhood between fellow human beings). KH. Abdurrahman Wahid as the central figure of NU gave an example of how beautiful brotherhood is with non-Muslims and minorities. The balance of the kiai is manifested in the form of providing constructive criticism and input for the government, so that they do not take a position as an opposition which sometimes only criticizes and exposes the government's disgrace and does not support absolutely without criticism of the government. The Qur'anic teaching 'tawashaw bil haqqi' voices the truth in favor of the interests of the people, consistently carried out by NU so that the government remains on the right track. NU's uprightness is proven by its efforts to give the best contribution to the nation and the state consistently and not swayed by persuasion and attacks that come.

NU is synonymous with moderate pesantren. Pesantren is a national asset, the pattern of character education applied in the pesantren learning system makes 
pesantren alumni have advantages over graduates of other educational institutions, especially in terms of mastery of religious knowledge, independence, national spirit, mutual cooperation and tolerance (Ghofarrozin \& Janah, 2021).

\section{Understanding Moderate Islam}

Moderate Islam is also called Islam Wasathiyyah. The word wasathiyyah has a close meaning, as said by Ibn Faris the letters wawu, shin and tha' in the correct form without the letters illat, meaning fair and middle. And the best (fairly anything) is the most middle or middle. The word al-wasthu has two forms. First, the word wasthu with the letter siin disukunkan means adverb of place (zharf) which means (baina / between). Second, the word wasatha with the letter siin is fatkhah, this word has various meanings that are close in meaning. It can be a noun that means something that is between two things, such as the expression "I cut off the middle (wasatha) of the bow". It can be a trait with the meaning of khiyar, afdhal, ajwad (best, most important) thus awsatah syar'i is the best and the most important (Rahman, 2020).

In language washatiyah (moderation) comes from the words wasatha, yasuthu, sathothan has various meanings, including in the middle, being between two ends, fair, in the middle or simple or mediocre. The word wasatha also means taking care of oneself in the nature of ifrath and tafrith. In the book of mu'jam al wasith the word wasathan means "adulan" and "khiyaran" which is simple and chosen. There are several verses of the Koran that mention the word wasath and its derivation, among others, in al-baqarah 143 and 238, al-qalam 28, al-isra 78. In the encyclopedia of al-quran the word wasatha means an intermediate position between two opposing positions. such as the word "dare" is in the position of "careless" and "afraid" (Maimun \& Qosim, 2019).

The word wasath in the verse contains various meanings among scholars' interpretation, namely the best meaning (khoiriyah), fair (adalah), intention (alqasd) and middle (at-tawasuth). Because of the many meanings, the commentators have different opinions about the meaning of the word call. The Prophet Muhammad interpreted the word wasathan in the above verse fairly, which means fair and putting something in its place. Carrying out the law of azimah in normal conditions and giving the law of rukhsoh in an emergency is fair. Changes in fatwas due to changes in situation and conditions as well as differences in legal stipulations due to 
differences in one's condition and psychology are fair (Muhajir, 2018). At-Thobari interprets the word wasath with the meaning of a position that is between the two poles, where Muslims do not have excessive nature and are not reluctant in a case, but are in a middle position.

The meaning of washatiyah in terms is Islamic values that are built on the basis of a straight and middle mindset, not excessive in certain respects. The sentence "ummatan wasatha" in al-Baqarah 143 means a just and elected or chosen people. This means that Muslims are Muslims who are perfect in religion, best in morals, most importantly in deeds, perfect and just people who are witnesses for all humans on the Day of Resurrection. The Wasatan Ummah is the chosen people of justice, the best, and has the vision of straightening the "hanif". That's why Muslims who have wasatiyah nature don't like extreme things either too right or left, don't just ignore materialism, and leave spiritualism, don't ignore spiritual life and leave the physical. It is not only concerned with individual interests and forgetting social interests, that is the true essence of Islam wasathiyah (Maimun dan Qosim, 2019).

$\mathrm{KH}$. Afifuddin Muhajir stated that moderation (wasatiyah) is every pattern of thinking, acting, and behavior that has the characteristics of tawasuth, tawazun and ta'adul. Washatiyyah character is inherent in Islam since this religion was born until the Day of Judgment. After there was a split in the body of Muslims, the nature of wasathiyyah was sticky with the Ahlus Sunnah wal Jama'ah (Aswaja) group. Wasathiyyah colors the teachings of creed, morals of Sufism and the teachings of the Shari'a and its methodology (manhaj) in Islamic life (Muhajir, 2018).

Kiai Sahal practices the wasathiyyah attitude in a life of pluralism. Whether it is related to local customs or related to differences in religion and belief. Especially in the context of mu'asyarah (association between fellow human beings) and in matters of mu'amalah (association related to economic activity). The attitude of Kiai Sahal in appreciating differences and pluralism does not mean that Kiai Sahal also follows the religious rituals of people of other religions. In this case, Kiai Sahal is firm in positioning himself and his beliefs when associating with various groups. Being tolerant and respecting pluralism does not mean dissolving in one belief and mixing up the teachings of one religion and the teachings of another. In the issue of religious pluralism, it can be seen that Kiai Sahal respects differences and maintains good relationships with adherents of other religions. However, on the other hand, he 
took care not to confuse religious beliefs and rituals with one another (Janah \& Baroroh, 2021).

Islam wasathiyyah received an important contribution by Mohammad Hasyim Kamali in his work "The Middle Path Of Moderation In Islam: The Qur'anic Principle Of Wasathiyyah" published by Oxford University Press in 2015. As in the title Kamali does not use the term Islam wasathiyyah which is commonly used in Indonesia, but he uses the term "the middle way of Islamic moderation based on the Qur'anic principle of wasathiyyah". In Indonesia, the term Islamic moderation or moderation in Islam which is related to the term moderate is often questioned by a handful of Muslims themselves. For them, Islam is only Islam, there is no Islamic moderation or moderate Islam, because that is why the term Islam wasatiyyah which is qur'ani and comes from the verses of the Qur'an (al-Baqarah: 143) is more accepted and more commonly used (Hasan, 2017).

This study wants to answer two problem formulations. First, what is the meaning of moderate Islam? Second, how to preach moderate Islam in the new normal era by KH. Afifuddin Muhajir and KH. Abdul Moqsith Ghazali? The method used in this research is a qualitative method. In essence, qualitative research is a systematic activity to explore theories from facts in the real world, not to test theories or hypotheses (Rukajat, 2018). This study uses a phenomenological approach. This study explores and parses the content used for da'wah via social media You Tube. The data source is obtained from online Koran content via you tube by KH. Afiffuddin Muhajir and KH. Abdul Moqsith Ghazali and also supported by literature, books, articles and thoughts by KH. Afiffuddin Muhajir and KH. Abdul Moqsith Ghazali.

The method used in this study is a qualitative method. This study uses a phenomenological approach. Analysis using discourse content analysis. The data analysis technique uses content analysis, which is a research technique that is carried out objectively, systematically and descriptions of the contents of visible communication (manifest). One of the important characteristics of content analysis is that it is objective. The research was conducted to get an overview of the contents as they are without any intervention from the researcher. This research eliminates bias, partiality, certain tendencies of the researcher (Eriyanto, 2015). Here the 
researcher will get a message from the contents of $\mathrm{KH}$ 's online recitation. Afifuddin Muhajir and KH Abdul Moqsith Ghazali.

\section{Results and Discussion}

\section{Biography of KH. Afifuddin Muhajir}

$\mathrm{KH}$. Afifuddin Muhajir is an Indonesian cleric known as faqih (fiqh expert) and ushuli (ushul fiqh expert) from the Salafiyyah Syafiyyah Islamic Boarding School Sukorejo Situbondo. He was born on May 20, 1955 in Sampang Madura. Education KH. Afifuddin Muhajir since Madrasah Ibtidaiyah, Madrasah Tsanawiyah, Madrasah Aliyah, and Universities are all from the Salafiyah Syafiyyah Sukorejo Islamic Boarding School, Situbondo, East Java. Thesis KH. Afifuddin Muhajir at the Ibrahimy Institute of Islamic Religion (IAII) Situbondo is the Qur'an between Firmness and Flexibility. Thesis KH. Afifuddin Muhajir at the Islamic University of Malang (UNISMA) is a Sharia Law between Firmness and Flexibility. KH. Afifuddin Muhajir is the Deputy Caretaker for the Scientific Development of the Salafiyah Syafiiyyah Islamic Boarding School Sukorejo Situbodno, East Java. He became the Chairman of the Naib Mudir Ma'had Aly Foundation at the Salafiyah Syafiiyyah Islamic Boarding School Sukorejo Situbondo, East Java. He became a member of the founding team and actively taught ushul fiqh at Ma'had Aly.

$\mathrm{He}$ is active in the Bahtsul Masail Syuriyah forum, starting at the Branch, Regional, and Central levels. He became Deputy Head of PBNU Syuriyah for the solemn period of 2000-2015 and is now one of PBNU's Deputy Rais Syuriyah. He is also one of the chairmen of the MUI (Indonesian Ulema Council). He has been active in teaching the yellow book to the students in the prayer room of the Salafiyyah Syafiiyyah Islamic Boarding School since his twenties until now, which is done regularly and istiqamah. He is also actively teaching at IAII and Ma'had Aly and is a resource person in various scientific discussion forums, both local, regional, national and international. There are many works of KH. Afifuddin Muhajir. One of them is Fathul Mujib al-Qarib, syarah book Taqrib, al-Luqmah As-Saighah, Fiqh Study Methodology, Anti-Corruption Jurisprudence (in the book Corruption of Religious People), Jurisprudence Against Direct Elections, Mashlahah as Ideals for Establishing Islamic Law, Building Islamic Reason Moderate, and others. 


\section{Biography of KH. Abdul Moqsith Ghazali}

KH. Abdul Moqsith Ghazali was born to the couple KH. Ahmad Ghazali and Hj. Siti Lutfiyah. He studied the Koran and basic fiqh books such as Sullam and Safinah from his mother. To his father, he studied qawaid fiqhiyyah and balaghah science. To his grandfather, KH. Syarifuddin Abd. Shomad, he studied nahwu and sharaf, starting from the Jurumiyyah book to the Syarah Ibn Aqil. He also studied Sufism books with his grandfather, such as Bidayatul Hidayah and Kifayatul Atqiya'.

His education started at SDN Arjasa 1 Arjasa Sumenep and then at SMPN Arjasa 1 Arjasa Sumenep. While the high school level is taken at Ibrahimy Sukorejo High School Situbondo. The boarding schools that he went through were the Zainul Huda Arjasa Sumenep Islamic Boarding School and the Sukorejo Asembagus Islamic Boarding School Situbondo. The higher education was taken at the Syari'ah Faculty (S1) IAI Ibrahimy Sukorejo Situbondo in 1990-1994. While the second degree (S2) and the third degree (S3) at UIN Syarif Hidayatullah and is now a lecturer at UIN Syarif Hidayatullah. 1995-1996, KH. Abdul MOqsith Ghazali took part in the PP's Clerical Insight Development Program. Lakpesdam NU Jakarta and attended the TOEFL WEBB International Language School for six months in Surabaya in 1995.

One of his works is: Typology of Sufism Thought Junaid al-Baghdadi (S2 Thesis), Arguments for Religious Pluralism, Building Tolerance Based on the Qur'an (S3 Dissertation), Upheaval in the NU Republic (Co-editing with Suwendi), NU Dynamics: A Social Journey from The 1994 Cipasung Congress to the 1999 Kediri Congress (Co-compiled with Suwendi), and others. He is active in discussion forums in various scientific discussion forums in the capital city of Jakarta, starting with PP. Lakpesdam NU, The Wahid Institute, P3M, Desantara, PSIK, PPSDM UIN Jakarta, PAramadina, Puan Amal Biologi, Rahima, PSIK, LSAF, STT Jakarta, eLSAD and others.

Thoughts KH. Afifuddin Muhajir and KH. Abdul Moqsith Ghazali From Ngaji Online:

A. KH. Afifuddin Muhajir

1. When Angry Don't Make Decisions

In the recitation of the book Jam'ul Jawami' chapter Masalikul 'Illah, KH. Afifuddin Muhajir explained that the scholars of ijma' (consensus) that the illat forbidding the Prophet to make decisions when angry is tasywisyul fikri (disrupting the mind). If the mind is confused, then the decisions taken are not 
fair (Youtube KH. Afifuddin Muhajir). Currently known group known for its anger. This group prioritizes emotions and behaviors that promote violence. Sweeping, bombing other places of worship, and conducting large-scale demonstrations against people and parties deemed to be harassing religion.

Thoughts KH. Afifuddin Muhajir above encourages Muslims to think and behave wisely, not to be angry, and to always prioritize maturity and wisdom. Emotions do not solve the problem and actually worsen the situation and condition. The prohibition of making decisions when angry requires Muslims to prioritize objective rationality rather than subjective emotions.

2. Glorifying Knowledgeable People

The commandment glorifies those who are knowledgeable. Knowledge is a trait that is the basis of respect and giving glory (Youtube KH. Afifuddin Muhajir). Pen respect because science becomes an important lesson so that there is no fanaticism and figure absolutism. Often blind fanaticism occurs without seeing a person's scientific capacity, but pure figurity-subjective bonds. Respecting people for their knowledge means high respect for the objectivity of science.

There are so many Islamic groups who are absolute fanatics regardless of one's scientific capacity. There are so many people who judge a person's capacity only because of the number of followers, the ability to speak in the future, and a wide network. This is what needs to be fixed.

3. Following the law based on Dhon for those who have Dhon and those who follow it

However, there is an opinion that cursing the dhon does not apply to people who argue. There is even an opinion that dhon is not an absolute proof (Youtube KH. Afifuddin Muhajir). This thought is an important lesson for Muslims not to think that their opinion is the best and judge others whose opinions are different from wrong, even misguided. Differences of opinion are a necessity, so they must be respected and used as discussion partners that enrich scientific treasures thoroughly.

Tolerance is needed so as not to claim that his opinion is the most correct. In the context of understanding Ahlussunnah Wal Jama'ah alone, there are four schools of thought with different legal methods, namely the Imam 
Hanafi schools, Imam Malik, Imam Syafii, and Imam Ahmad bin Hanbal. The four are treasures of thought that must be developed continuously in order to be able to respond to the dynamics of the times.

4. The Reason for War Is Al-Hirabah, The Destructive Behavior Performed

This reason is supported by the Hanafi, Malikiyah and Hanabilah. Meanwhile, according to the Imam Shafii madhhab is al-kufru (Youtube KH. Afifuddin Muhajir). The view of the non-Shafi'iyyah majority is very relevant in the current era. Of course this does not state that the views of Shafi'iyyah are irrelevant. The sociological-historical study of the birth of a view is very interesting to do before declaring that a view is irrelevant. It is very possible that Imam Shafii's view was that the reason for the war was al-kufru because at that time the infidels were actively fighting Muslims. That is, infidels do hirabah, destructive behavior, especially to Muslims.

The present era is certainly different from the previous era. Currently, the state is based on an agreement so that brotherhood and cooperation are put forward and primordial-subjective ties are eliminated in order to realize progress in all aspects of life. Various progressive views are accommodated so that progress can be achieved and divisions avoided as early as possible.

5. Prohibition of criticizing, accusing, etc. to maintain honor

Mutual respect for each other is the key to a harmonious life. Islam forbids criticizing, bullying, exposing other people's disgrace, backbiting, and other things that damage brotherhood and cause division (Youtube KH. Afifuddin Muhajir). National unity is the main key in development. If society is plagued with conflict, agitation, and confrontation, then this religion cannot be enforced properly and correctly and things that are contrary to religion will become an unavoidable reality.

Therefore, maintaining honor is something that cannot be negotiated. If all elements of the nation maintain the honor of others, then life will run harmoniously, progressively, and humanistically. Cooperation in goodness will be the driving force towards the achievement of progress in all fields towards the achievement of inner and outer happiness, this world and the hereafter. 
6. Upholding Justice and Equality

In religion there are five main principles, namely protecting religion, soul, mind, property, and offspring. These five main principles are called ummatul maqashid (mother of maqashid) or ummatul mashalih (mother of benefit). In addition to these five main principles there are offshoots. Among other things: justice and equality (Youtube KH. Afifuddin Muhajir). Justice and equality are crucial things in today's era. Justice is enforcing the law without discrimination, giving things according to the rules, and being oriented to the public welfare. Equality encourages the emancipation of women so that they are both actors in nation building. The collective contribution of men and women will accelerate the achievement of nation building in all aspects of life.

Justice and equality are the foundations of the nation that encourage citizens to actively participate in building society. In addition, the government with all its instruments must improve its transparency, credibility, accountability, and integrity so that the program is truly oriented to the substantial benefit.

7. The good and the bad of something follow the good and the bad. If something contains benefit, then the name is good and if it contains harm then the name is bad.

KH. Afifuddin Muhajir is one of the scholars who put benefit in the main position. The law must contain benefits so that in its grounding it really brings real benefits in the community and avoids damage in any aspect (Youtube $\mathrm{KH}$. Afifuddin Muhajir). Until the law only shows the side of formality, but the substance is dry which leads to the grounding of benefits. Benefit is to bring benefits to the world and the hereafter and reject the damage of the world and the hereafter. This benefit is the main parameter of the law. Imam Ghazali in the book Al-Mustashfa explains, this benefit is the benefit of the Creator ( $\mathrm{Al}$ Khaliq). However, Khaliq's benefit is still oriented to the problems of creatures because it revolves around five things. Namely: guarding religion, soul, mind, property, and offspring.

Currently, there are many Islamic groups who only see formality without examining the philosophical meaning behind a doctrine. In the end, they took action to damage the public with a mission: to enforce Islamic law according to 
their understanding, even though it violated other Islamic laws. This is where the thoughts of $\mathrm{KH}$. Afifuddin Muhajir is relevant so that Islam is able to present itself as a religion that binds the nation and unites the people in order to achieve collective progress.

B. KH. Abdul Moqsith Ghazali

1. The Law of Killing Infidels

In reciting the book Syarah waraqat fi ushulil fiqh series 9, KH Abdul Moqsith Ghozali explains that the verse in Surah At-Taubah is "faqtulul musyrikina haisu wa jad tumuhum (you kill the polytheists wherever you meet them)" (Youtube KH. Abdul Moqsith Ghazali). This verse was revealed in an emergency situation of war. The question is whether all the polytheists were killed? apparently not, there are muahaq infidels who should not be killed, the verse is the verse "command to kill", al musyrikuna is an am (general) verse, because it is plural that concedes al, but its generality is limited by the verse "illaldina ahadtum minal musyrikina. .. ", those who are not allowed to be killed are unbelievers who are bound by a pact with Muslims, so not all infidels are killed, unbelievers who are in agreement with Muslims cannot be killed. The verse "illaladina ahadtum ..." is a mukhosis (exception) to the verse "faqtulul musyrikina ... ", so it is wrong if we apply this verse without considering the verse that is the mukhosis, some infidels are excluded as the prophet said "man is dimmyan faqod adani" which means "anyone who hurts an infidel Dimmy is the same as hurting me", therefore an infidel dimmy cannot be killed, he is excluded from the verse above. Another example is that it is obligatory for a Muslim to fast during Ramadan, except for a Muslim who is sick or on a journey. So every pronunciation of am must have an exception.

2. Prohibition of Friday Prayers During Covid 19

Sayyid Thantawi's recitation of the book of Tafseer al-Wasith Sayyid Thantawi Surat al-Baqarah series 4 (Youtube KH. Abdul Moqsith Ghazali). KH Abdul Moqsith Ghazali stated that Friday prayers were prescribed after the Prophet was 2 years in Medina, that's why in the Qur'an there is a Surah Al Jumuah, Friday prayers must be done in congregation . Our ulema' in the face of this covid-19 pandemic do not allow the implementation of Friday prayers, actually what is prohibited is not the Friday prayers, but the gathering activity 
that causes one to be infected by the other because we do not know who has the virus. The ulama' who gave this fatwa were big scholars such as the fatwa of al-Azhar scholars, the batshul Masail Nahdlatul Ulama', the fatwa commission of the Indonesian Ulama Council which stated that if you have entered the red zone, gathering activities are prohibited. Friday prayers are obligatory, so to prohibit gathering activities requires a fatwa, but if you go to malls, markets, terminals and others, you don't need a fatwa because it is a permissible activity. The government can directly prohibit with various considerations. So it can be understood that what is prohibited is not the Friday prayer, but the amrun khoriji (something outside the Friday prayer) namely gathering activities.

3. Evil is rewarded with evil or patience and forgiveness

In the syarah hikam recitation series 3 (Youtube KH. Abdul Moqsith Ghazali). KH Abdul Moqsith Ghazali explained about the verse of the quran "wajzau sayyiatiin sayyiatun misluha", meaning that if other people do bad things, it is permissible to repay them with the same evil. When a Sufi is abused, humiliated, humiliated and put down, it is a bad deed, but what comes out of his mouth is still good, not cursing, not abusing. Most of us are not like that, if we are insulted have a tendency to retaliate. "walaman sobaro waghofaro fainna dalika lamin azmil age". If we are patient and forgive then it becomes the behavior of the prophets who we call ulul azmi, namely noble people. It is like a Sufi who is westernized with the earth. Throwing the bad is repaid with the good.

4. Suicide For Any Reason Is Not Justified

The study of the Tafsir Jalalin series 4 (Youtube KH. Abdul Moqsith Ghazali). KH Abdul Moqsith Ghazali explained in the new testament there was a story that was interpreted by some Christians about the words of Jesus "there is no way of salvation except me and the way of suffering." That salvation is me, I have come not to destroy the Torah but to fulfill it." But in the belief of Muslims, the last prophet was Muhammad whose job was to compile pre-existing laws that were not in accordance with the times. The Shari'a before Islam was modified or changed, for example there was a Shari'a that it was permissible to commit suicide as penance, then the Shari'a was abolished by the Shari'a of 
suicide as penance. This is no longer allowed, so suicide for any reason, including jihad reasons, is not justified. In war, when the enemy kills, it is jihad, but the Prophet and his companions never took the example of killing oneself. In Surah Al-Baqarah 195 "and do not throw yourself into destruction, and do good, because Allah loves those who do good". This verse very clearly explains that jihad by suicide is not justified, the true jihad is jihad that is in accordance with the commands of the prophet.

5. The Prophet's Political Behavior Is Not Shari'a

During the recitation of the syarah waraqat fi ushulil fiqh (Youtube KH. Abdul Moqsith Ghazali). KH Abdul Moqsith Ghazali explained about his book Ali Abdul Razi entitled "al-islam wa ushulul hukmi", (this book was widely rejected by scholars in Egypt which was published in 1925). In it there is a question "hal kana ta'sisu nabi bidaulatin siyasiyah juz'an min risatraini amalah" which means "were the political actions and behavior of the Prophet in Medina a part of the prophetic treatise or not?", some scholars stated that it was not part of the prophetic treatise, because if we follow the prophet in this matter it can be dangerous in the present context. When the Prophet was in Medina, the legislative, executive and judicial powers were in the hands of the prophet. Because the Prophet who is ma'sum holds 3 powers in his hands at the same time, it is harmless. It is conceivable in the modern era now or besides the Prophet there are people who are President as well as Chairman of the DPR and MPR as well as Chairman of the Supreme Court (Indonesian context), how dangerous that power is, so to minimize disgraceful acts, modern society finally takes power-sharing actions called trias politica. Trias politica has no evidence in the Qur'an and hadith but contains benefits. In qoidah muamalah, when there is no evidence that prohibits it, it shows that the act is permissible (syar'i), then it is permissible and the action is included in the actions of the Prophet.

6. Avoiding Unnecessary Debate

KH Moqsith Ghazali when reciting syarah hikam series 5 (Youtube KH. Abdul Moqsith Ghazali). told the story of Ma'ruf Al Kharfi who said "if Allah wants someone to be a good person, then Allah opens the door so that he can perform worship well and closes the door so that he does not argue a lot, if Allah 
wants a servant to be a bad person, so the door for him to be diligent in doing good deeds is closed, what is opened is the door for encouragement to argue." Many Sufis avoid unnecessary debates. Like spending time on social media arguing over things unnecessarily. The Prophet said "min khusni islamil mar'i tarkuhu mala ie" means that a good Muslim avoids something that is useless, but sometimes humans need something fun to avoid boredom. When it is something that is permissible and does not cause harm, then it is permissible.

7. Differences of Opinion Among Ulama' Are a Mercy for All Humanity

One of the explanations of KH Abdul Moqsith Ghazali while studying the book of syarah waraqat fiy ushul fiqh series 7 , discussed differences of opinion among scholars, including scholars in Indonesia (Youtube KH. Abdul Moqsith Ghazali). These differences of opinion are often triggered because of differences in understanding the arguments or differences in using the arguments as long as these differences do not touch the essence of religious teachings, then the differences of opinion are a blessing for all mankind. Differences of opinion should not be based on qath'i arguments. The difference of opinion is not an curse, but Muslims can choose between the opinions of the ulama' A, B, C and D. We can follow the opinions of the ulama' who allow it, or follow the scholars' who do not allow something as long as it does not touch the main things in the law. Islam, so we follow one ulema' sect and leave the other 'ulama' is something that is legal in Islamic law. There is no need to be fanatical about one scholar's opinion by blaming another scholar's opinion.

More easily, read the table below:

Table 1. Moderate Islamic Da'wah

KH. Afifuddin Muhajir and KH. Abdul Moqsith Ghazali

\begin{tabular}{|c|c|c|}
\hline NO & KH. AFIFUDDIN MUHAJIR & KH. ABDUL MOQSITH GHAZALI \\
\hline 1 & When Angry Don't Make Decisions & The Law of Killing Infidels \\
\hline 2 & Glorifying Knowledgeable People & $\begin{array}{l}\text { Prohibition of Friday Prayers During } \\
\text { Covid } 19\end{array}$ \\
\hline 3 & $\begin{array}{c}\text { Following the Law Based on Dhon For } \\
\text { Those Who Have Dhon and Those Who } \\
\text { Follow It }\end{array}$ & $\begin{array}{l}\text { Evil is rewarded with evil or patience } \\
\text { and forgiveness }\end{array}$ \\
\hline 4 & $\begin{array}{c}\text { The Reason for War is Al-Hiramah, } \\
\text { Destructive Behavior }\end{array}$ & Suicide For An \\
\hline 5 & $\begin{array}{c}\text { Prohibition of Criticizing, Accusing, and } \\
\text { Others To Maintain Honor }\end{array}$ & $\begin{array}{l}\text { The Study of the Prophet's Political } \\
\text { Behavior }\end{array}$ \\
\hline 6 & Upholding Justice and Equality & Avoiding Unnecessary Debate \\
\hline 7 & $\begin{array}{l}\text { The good or bad of something follows } \\
\text { the benefit and the damage it contains }\end{array}$ & $\begin{array}{l}\text { Differences of Opinion Among Ulama' } \\
\text { Are a Mercy for All Humanity }\end{array}$ \\
\hline
\end{tabular}


Moderate Islamic da'wah delivered by KH. Afifuddin Muhajir and KH. Abdul Moqsith Ghazali online solidifies the foundations of moderate Islam. The online da'wah of moderate Islam carried out by these two scholars is relevant to the seven characteristics of moderate Islam. The description is as follows:

The moderate Islamic da'wah doctrine of KH. Afifuddin Muhajir and KH. Abdul Moqsith Ghazali according to the principles of divinity and prophetic instructions. Both thoughts are based on the Qur'an and a deep understanding of the Prophet's hadith. The reasons for war because of destructive behavior and reasons for killing non-Muslims that threaten the existence of Muslims cannot be separated from a deep understanding of the Qur'an Surah At-Taubah 4-7 and QS. Al-Maidah verse 33.

Thoughts KH. Afifuddin Muhajir and KH. Abdul Moqsith Ghazali is in accordance with the nature of humanity that wants holiness, glory, and happiness. The prohibition of criticizing, accusing, and killing for any reason shows this character. Life will run peacefully, harmoniously, and full of happiness if one another respects, respects, and glorifies one another.

Thoughts KH. Afifuddin Muhajir and KH. Abdul Moqsith Ghazali according to the character of avoiding conflict. Difference of opinion is a blessing and one should not impose his thoughts on others is the proof. Each person has his own thoughts and tendencies that must be respected by one another. Moderate Islam has a high tolerance for differences and stays away from the absolutism of thoughts that are harmful to unity and diversity.

Thoughts KH. Afifuddin Muhajir and KH. Abdul Moqsith Ghazali is consistent with a steady and consistent character, especially in the aspect of glorifying people who are knowledgeable and avoiding unnecessary debates. This thinking encourages people to consistently develop science and avoid debates that are counterproductive to the progress of science and social harmony.

Thoughts KH. Afifuddin Muhajir and KH. Abdul Moqsith Ghazali is in accordance with the universal and comprehensive character, especially in the orientation of benefit and forgiving the mistakes of others. Benefit is the goal of a comprehensive Islamic Shari'a that maintains the sanctity of religion, soul, property, intellect, and lineage. Meanwhile, forgiving the mistakes of others is proof of the universality of moderate Islamic values which upholds the greatness of morality and 
the sanctity of behavior in social interactions. It is this behavior that cools, reconciles, and binds all social elements.

Thoughts KH. Afifuddin Muhajir and KH. Abdul Moqsith Ghazali is in accordance with the last moderate Islamic character, namely showing balance, wisdom, and being free from excessive actions. The thought of prohibiting making decisions when angry and Friday prayers during covid 19 are evidence of thoughts that imply wisdom, balance, and avoid overdoing it. The culture of anger and extremes in making decisions and taking action is the cause of polarization of the people which undermines national unity and disrupts the nation's development agenda.

Islamic Da'wah online KH. Afifuddin Muhajir and KH. Abdul Moqsith Ghazali according to the seven characteristics of Islam moderate.

More clearly see in the table below:

Table 2. Analysis of Moderate Islamic Preaching

KH. Afifuddin Muhajir And KH. Abdul Moqsith Ghazali

\begin{tabular}{|c|c|c|c|c|}
\hline NO & $\begin{array}{l}\text { KH. AFIFUDDIN } \\
\text { MUHAJIR }\end{array}$ & $\begin{array}{c}\text { KH. ABDUL } \\
\text { MOQSITH GHAZALI }\end{array}$ & CHARACTERISTICS & DESCRIPTION \\
\hline 1 & $\begin{array}{c}\text { Everything, } \\
\text { Especially the } \\
\text { Reason for War is } \\
\text { Al-Hirabah, } \\
\text { Destructive } \\
\text { Behavior }\end{array}$ & $\begin{array}{l}\text { Everything, Especially } \\
\text { the Law of Killing } \\
\text { Infidels }\end{array}$ & $\begin{array}{l}\text { Based on God } \\
\text { (Rububiyah) }\end{array}$ & $\begin{array}{l}\text { Al-Qur'an Surah At- } \\
\text { Tawbat verses 4-7 } \\
\text { explains this }\end{array}$ \\
\hline 2 & $\begin{array}{c}\text { Everyone, Especially } \\
\text { Upholding Justice } \\
\text { and Equality }\end{array}$ & $\begin{array}{c}\text { Everything, Especially } \\
\text { the Study of the } \\
\text { Prophet's Political } \\
\text { Behavior }\end{array}$ & $\begin{array}{l}\text { Based on Prophetic } \\
\text { Instructions }\end{array}$ & $\begin{array}{l}\text { The Prophet's political } \\
\text { behavior was aimed at } \\
\text { upholding justice and } \\
\text { substantial equality }\end{array}$ \\
\hline 3 & $\begin{array}{l}\text { Prohibition of } \\
\text { Criticizing, Accusing, } \\
\text { and Others To } \\
\text { Maintain Honor }\end{array}$ & $\begin{array}{l}\text { Suicide For Any } \\
\text { Reason Is Not } \\
\text { Justified }\end{array}$ & $\begin{array}{l}\text { Compatible With } \\
\text { Human Fithrah }\end{array}$ & $\begin{array}{l}\text { Keeping human nature to } \\
\text { remain honorable }\end{array}$ \\
\hline 4 & $\begin{array}{c}\text { Following the Law } \\
\text { Based on Dhon For } \\
\text { Those Who Have } \\
\text { Dhon and Those } \\
\text { Who Follow It }\end{array}$ & $\begin{array}{c}\text { Differences of Opinion } \\
\text { Among Ulama' Are a } \\
\text { Mercy for All } \\
\text { Humanity }\end{array}$ & Avoid Conflict & $\begin{array}{c}\text { Accommodating } \\
\text { differences and achieving } \\
\text { progress }\end{array}$ \\
\hline 5 & $\begin{array}{c}\text { Glorifying } \\
\text { Knowledgeable } \\
\text { People } \\
\end{array}$ & $\begin{array}{c}\text { Avoiding Unnecessary } \\
\text { Debate }\end{array}$ & $\begin{array}{l}\text { Steady and } \\
\text { Consistent }\end{array}$ & $\begin{array}{l}\text { Consistent in giving birth } \\
\text { to new knowledge and } \\
\text { thoughts }\end{array}$ \\
\hline 6 & $\begin{array}{l}\text { The good or bad of } \\
\text { something follows } \\
\text { the benefit and the } \\
\text { damage it contains }\end{array}$ & $\begin{array}{l}\text { Evil is rewarded with } \\
\text { evil or patience and } \\
\text { forgiveness }\end{array}$ & $\begin{array}{l}\text { Universally Loaded } \\
\text { And Comprehensive }\end{array}$ & $\begin{array}{l}\text { Always oriented to the } \\
\text { enforcement of } \\
\text { substantial benefits }\end{array}$ \\
\hline 7 & $\begin{array}{l}\text { When Angry Don't } \\
\text { Make Decisions }\end{array}$ & $\begin{array}{c}\text { Prohibition of Friday } \\
\text { Prayers During Covid } \\
19\end{array}$ & $\begin{array}{l}\text { Wise, Balanced, And } \\
\text { Free From Excessive } \\
\text { Action }\end{array}$ & $\begin{array}{l}\text { Avoid extremities and } \\
\text { maintain balance }\end{array}$ \\
\hline
\end{tabular}


The findings in this study are rationalist-humanist-style da'wah is da'wah in the way of thinking al-adalah, at-tawazun, at-tawasuth and at-tasamuh which makes human beings an object that should be respected and valued as a creature of God's creation. Moderate Islamic da'wah carried in the online study of KH. Afifuddin Muhajir and KH. Abdul Moqsith Ghazali provides a high portion of reasoning in understanding the Qur'an, sunnah, and the thoughts of the scholars. In addition, the moderate Islamic da'wah of these two scholars aims to humanize humans by placing humans in a noble position whose honor must be maintained in accordance with the nature of holiness.

\section{Conclusion}

Moderate Islamic da'wah by KH. Afifuddin Muhajir and KH. Abdul Moqsith online corresponds to the seven characteristics of moderate Islam. Da'wah KH. Afifuddin Muhajir contains several doctrines, including: when angry it is forbidden to make decisions, glorify people who are knowledgeable, follow the law based on dhon for those who have dhon and those who follow it, the reason for war is alhirabah, destructive behavior, prohibition of criticizing, accusing, and others to maintain honor, uphold justice and equality, and the good or bad of something follows the benefit and damage it contains. While the preaching of $\mathrm{KH}$. Abdul Moqsith Ghazali are: the law of killing unbelievers, the prohibition of Friday prayers during covid-19, evil is rewarded with ugliness or patience and forgiveness, suicide for any reason is not justified, the Prophet's political behavior, avoiding unnecessary debates, and differences of opinion among scholars is a mercy for all mankind.

The findings of this study are rationalist-humanist moderate Islamic da'wah. Moderate Islamic da'wah carried by KH. Afifuddin Muhajir and KH. Abdul Moqsith Ghazali provides a high portion of reasoning and is oriented towards human respect. Both of them are experts in ushul fiqh and study Sufism, so that these two disciplines greatly influence their thinking so that they have a rationalist-humanist pattern.

\section{Acknowledgment}

This paper and the research behind it would not have been possible without the exceptional support of Department for Research and Community Outreaches (LPPM) IPMAFA Pati. 


\section{Bibliography}

Abdullah, M. Q. (2019). Pengantar Ilmu Dakwah. Surabaya: Qiara Media

Al Bayanuni, M. A. (2021). Al Madkhal Ila Ilmi Ad Dakwah, Terjemahan Pengantar Studi Ilmu Dakwah. Jakarta: Pustaka Al-Kautsar

Anggito, A., Setiawan, J. (2018). Metodologi Penelitan Kualitatif. Sukabumi: CV Jejak

Baidowi, A., Solehoddin, M. (2021). Strategi Dakwah Di Era New Normal. Jurnal Muttaqien, Vol.2 No.1

Budiyanto, O. W., Rahmanto, T. Y. (2021). Pencegahan Paham Radikalisme Melalui Optimalisasi Pendidikan Hak Asasi Manusia di Indonesia. Jurnal HAM. Vol 12 No.1

Eriyanto. (2015). Analisis Isi: Pengantar Metodologi untuk Penelitian Ilmu Komunikasi dan Ilmu Sosial Lainnya. Jakarta: Kencana

Fatikh, M. A. (2020). Tantangan Komunikasi Islam Moderat Di Era New Media. Jurnal Al-Tsiqoh (Dakwah dan Ekonomi). Vol. 5 No.2

Ghazali, A. M. (2009). Argumen Pluralisme Agama, Membangun Toleransi Berbasis AlQur'an. cet. 2. Depok: Kata Kita

Ghofarrozin, A., Janah, T. N. (2021). Menakar Keberpihakan Negara Terhadap Pesantren Melalui Pengesahan UU No 18 Tahun 2019. Islamic Review: Jurnal Riset dan Kajian Keislaman. Vol.10 No. 1

Hannan, A. (2018). Islam Moderat dan Tradisi Popular Pesantren: Strategi Penguatan Islam Moderat di Kalangan Masyarakat Madura Melalui Nilai Tradisi Popular Islam Berbasis Pesantren. Dialektika. Vol. 13 No. 2

Hasan, M. (2017) Moderasi Islam Nusantara (Studi Konsep Dan Metodologis), Pamekasan: Duta Media Publishing.

Janah, T. N., Baroroh, U. (2021). Pluralism In The Fiqh Sosial's Perspective. Santri: Journal of Pesantren and Fiqh Sosial. Vol.2 No.1

Maimun., Qosim, M. (2019). Moderasi Islam di Indonesia. Yoyakarta: LKiS

Muhajir, A. (2017). Fiqh Tata Negara, Upaya Mendialogkan Sistem Ketatanegaraan Islam. Yogyakarta: Ircisod

Muhajir, A. (2018). Membangun Nalar Islam Moderat, Kajian Metodologis cet. 2, Situbondo: Tanwirul Afkar

Pirol, A. (2018). Komunikasi dan Dakwah Islam. Sleman: Deepublish

Rahman, S. (2020). Wasathiyyah dalam Al-Quran: Nilai-Nilai Moderasi Islam dalam Akidah, Syariah, dan Akhlak. Terj, Al-Wasathiyyah Fil Qur'anil Karim. Jakarta: Pustaka Al-Kautsar

Rukajat, A. (2018). Pendekatan Penelitian Kualitatif. Sleman: Deepublish

Thoifah, I.; et.al. (2020). Ilmu Dakwah Praktis Dakwah Milenial. Malang: UMM Press

Zamimah, I. (2018). Moderatisme Islam dalam Konteks Keindonesian (Studi Penafsiran Islam Moderat M Quraish Shihab). Al-Fanar: Jurnal Ilmu Al-Qur'an dan Tafsir. Vol 1 No. 1 


\section{Youtube}

KH. Abdul Moqsith Ghazali recites the book of syarah waraqat fiy ushul fiqh series 7 . Link: https://www.youtube.com/watch?v=kcR4 6t8xuA

KH. Abdul Moqsith Ghozali Online study of the book of Syarah waraqat fi ushulil fiqh series 9, Link: https://www.youtube.com/watch?v=1GJEhIerCP0

KH. Abdul Moqsith Ghozali, Online Study of Al Wasith Sayyid Thantawi Surah AlBaqarah Series 4, Link: https://www.youtube.com/watch?v=0uEoCuk2Xps

KH. Abdul Moqsith Ghozali, Online Study on the interpretation of jalalin series 4, Link: https://www.youtube.com/watch?v=gdUbwY-IKLc

KH. Abdul Moqsith Ghozali, Recitation of syarah waraqat fi ushulil fiqh, Link: https://www.youtube.com/watch?v=WGUE-ogLgw8

KH. Abdul Moqsith Ghozali, Syarah Hikam online study series 3, Link: https://www.youtube.com/watch?v=SFH9L2dboe8

KH. Abdul Moqsith Ghazali, Online Ngaji syarah hikam series 5, Link: https://www.youtube.com/watch?v=gVZXZUi4rHI

KH. Afifuddin Muhajir, Jam'ul Jawami' Book Online Study on Youtube, 7 March 2021. Link: https://www.youtube.com/watch?v=9nFjxVMISPo

KH. Afifuddin Muhajir, Online study of the book Jam'ul Jawami' KH. Afifuddin Muhajir on $\quad$ Youtube, 28 March 2021, https://www.youtube.com/watch?v=7sNbMie rls

$\mathrm{KH}$. Afifuddin Muhajir, Online study of the book Jam'ul Jawami' on Youtube, March 14, 2021. Link: https://www.youtube.com/watch?v=30wqal0jRz8

KH. Afifuddin Muhajir, Online study of the book Jam'ul Jawami' on Youtube, March 14, 2021. Link: https://www.youtube.com/watch?v=30wqal0jRz8

KH. Afifuddin Muhajir, Online study of the book Jam'ul Jawami' on Youtue, 28 March 2021, https://www.youtube.com/watch?v=7sNbMie rls

KH. Afifuddin Muhajir, Online study of the book Jam'ul Jawami' on Youtue, 28 March 2021, https://www.youtube.com/watch?v=7sNbMie rls 
Moderate Islamic Da'wah in the New Normal Era... 